\title{
Influence of heat treatment on physicochemical and rheological characteristics of natural yogurts
}

\section{Influência do tratamento térmico nas características físico-químicas e reológicas de iogurtes naturais}

\author{
Juliana Aparecida Célia ${ }^{1}$; Marco Antônio Pereira da Silva ${ }^{2 *}$; \\ Kênia Borges de Oliveira ${ }^{1}$; Diene Gonçalves Souza ${ }^{1}$; Ligia Campos de Moura \\ Silva ${ }^{1}$; Edmar Soares Nicolau ${ }^{3}$; João Antônio Gonçalves e Silva ${ }^{4}$
}

\begin{abstract}
The aim of this study was to assess the influence of heat treatment on physicochemical and rheological characteristics of natural yogurts, as well as the influence of lyophilization process on natural yogurts after reconstitution. In the first experiment, three yogurt treatments were processed, as follows: Treatment 1 , yogurt produced with raw refrigerated milk; Treatment 2 , yogurt produced with refrigerated pasteurized milk; and Treatment 3 , yogurt produced with UHT (ultra-high temperature) milk, in addition to analyses of fat, protein, moisture, titratable acidity, and $\mathrm{pH}$. The shelf life of yogurts at $1,8,15,22$, and 29 days of storage, as well as $\mathrm{pH}$, acidity, syneresis, viscosity, viable lactic bacteria, and total coliforms were also assessed. In the second experiment, yogurts were submitted to lyophilization process, performed by scanning electron microscopy analysis and subsequently in those reconstituted, in addition to being assessed the physicochemical, rheological, and viable lactic bacteria characteristics. The results found in the first experiment showed that heat treatment was positive for viscosity, syneresis, and lactic bacteria, being viable until the 15th day of storage only for yogurts submitted to heat treatment. In the second experiment, lyophilization preserved the physicochemical characteristics of yogurts, but the number of initial lactic bacteria was different, also negatively affecting yogurt viscosity.
\end{abstract}

Key words: Acidity. Viable lactic cells. Lyophilization. pH. Shelf life.

\section{Resumo}

Objetivou-se avaliar a influência do tratamento térmico nas características físico-químicas e reológicas de iogurtes naturais e a influência do processo de liofilização em iogurtes naturais após sua reconstituição. No primeiro experimento, foram processados três tratamentos de iogurtes Tratamento 1 - iogurte produzido com leite cru refrigerado; Tratamento 2 - iogurte produzido com leite pasteurizado refrigerado; Tratamento 3 - iogurte produzido com leite UAT (Ultra Alta Temperatura) e feitas as análises de gordura, proteína, umidade, acidez titulável e $\mathrm{pH}$. Avaliou-se também a vida de prateleira dos iogurtes nos tempos 1, 8, 15, 22 e 29 dias de armazenamento, tendo sido feitas as análises de $\mathrm{pH}$, acidez, sinérese, viscosidade, bactérias lácticas viáveis e coliformes totais. No experimento II, os iogurtes foram submetidos ao processo de liofilização realizado analise de microscopia eletrônica de varredura

\footnotetext{
1 Mestres em Zootecnia, Instituto Federal Goiano, IFG, Campus Rio Verde, Rio Verde, GO, Brasil. E-mail: juliana.rv@hotmail. com; keniaborges_2008@hotmail.com; diene gsouza@hotmail.com; ligialirios@hotmail.com

2 Prof., IFG, Rio Verde, GO, Brasil. E-mail: marcotonyrv@yahoo.com.br

3 Prof., Universidade Federal de Goiás, UFG, Goiânia, GO, Brasil. E-mail: rena@cpa.evz.ufg.br

4 Discente, IFG, Rio Verde, GO, Brasil. E-mail: joaoantoniogs@agronomo.eng.br

Author for correspondence
}

Received: Aug. 30, 2015 Approved: May 30, 2017 
e, em seguida reconstituídos, e avaliadas as características físico-químicas, reológicas e de bactérias lácticas viáveis. Os resultados encontrados no primeiro experimento evidenciaram que o tratamento térmico foi positivo para viscosidade, sinérese e também para as bactérias lácticas, que foram viáveis até o $15^{\circ}$ dia de armazenamento apenas para os iogurtes submetidos ao tratamento térmico. No segundo experimento, constatou-se que a liofilização preservou as características físico-químicas dos iogurtes, os números de bactérias lácticas iniciais não foram mantidas, tendo também afetado negativamente a viscosidade dos iogurtes.

Palavras-chave: Acidez. Células lácticas viáveis. Liofilização. pH. Vida de prateleira.

\section{Introduction}

Yogurt is one of the most popular fermented products in Brazil and in the world, with a growing consumption in the dairy segment (MEDEIROS et al., 2010). The demand and consumption of yogurts have been intensified every year and market development is provided by its sensorial characteristics, combined with its nutritional properties (SILVA et al., 2012).

Yogurt is defined as the product whose fermentation is carried out with cultures of Streptococcus salivarius subsp. Thermophilus and Lactobacillus delbrueckii subsp. Bulgaricus, which can be followed in a complementary way by other acid-lactic bacteria that, by their activity, contribute to determine the final product characteristics (BRASIL, 2007).

According to Arashiro et al. (2006), the growing domestic market competitiveness, coupled with Brazil's intention to enter the international dairy market, lead the dairy industry increasingly seek technologies that make the products more efficient to meet market demand (ROCHA, 2005).

The knowledge generated regarding the influence of long storage periods after processing on yogurts has been extremely important in order to obtain information about their shelf life, demonstrate acceptable physical, chemical, or sensory characteristics for consumption, and determine the viability of lactic bacteria (PEREZ et al., 2007). According to Brazilian legislation (BRASIL, 2007), yogurt must present a viable cell counting of at least $10^{7} \mathrm{CFU} / \mathrm{mL}$ during its shelf life.
A more recent technique, dating from the $1950 \mathrm{~s}$, which has been gaining ground in the food industry, is the lyophilization. It is a widely used technique to preserve the original product characteristics, which would be impossible with the conventional drying techniques (FELLOEWS, 2000).

Lyophilization is the drying process in which the free water contained in the product passes from the solid state to the gaseous state by the sublimation phenomenon, aiming at a longer shelf life without affecting the physical and chemical food characteristics (SOUZA et al., 2013).

Lyophilized food has advantages over frozen food because the shelf life is longer and storage and transport costs are low. After lyophilizing, food should be stored in containers that prevent the entry of oxygen. In this sense, this study aimed to analyze the physicochemical and rheological characteristics of yogurts produced with different heat treatments such as raw refrigerated, pasteurized, and UHT (ultra-high temperature) milk, as well as its lyophilization and subsequently its reconstitution and assessment of physicochemical, rheological, and viable lactic cell characteristics.

\section{Material and Methods}

\section{Experiment setup}

This research was conducted from March to April 2015 in the Laboratory of Animal Origin Products of the Federal Institute of Education, Science, and Technology of Goiás, campus of Rio Verde, located in Rio Verde, GO, Brazil. The milk used in the 
experiment was purchased from a dairy industry located in Santa Helena de Goiás - GO, Brazil.

Two experiments were carried out. Experiment I assessed the raw material (milk) physicochemical characteristics, processing of natural yogurts (three treatments), assessment of physicochemical, microbiological, and rheological characteristics, and shelf life of natural yogurts during 29 days of storage. In Experiment II, natural yogurts were lyophilized on the 8th day of storage (corresponding to body, texture, and flavor formation); after 22 days of storage, yogurt storage after lyophilization was simulated, being the yogurt reconstituted and performed the physicochemical and rheological analyses, in addition to lactic bacteria counting.

\section{Raw material}

A total of $45 \mathrm{~L}$ (30 L refrigerated and 15 L UHT) of milk were purchased from the same storage silo. The refrigerated milk was transported in a presanitized container with a 30-L capacity and the UHT milk was transported in Tetra Pak packaging to the Laboratory of Animal Origin Products.

The 30-L refrigerated milk was divided into two treatments: $15 \mathrm{~L}$ of raw refrigerated milk and $15 \mathrm{~L}$ of pasteurized milk. Subsequently, samples with three replications and in triplicates were collected in bottles containing bronopol for chemical analyses.

The contents of fat, protein, lactose, and defatted dry extract (DDE) were determined by using the equipment Milkoscan 4000 (Foss Electric A/S, Hillerod, Denmark), with results expressed in percentage. For electronic assessment, milk samples were conditioned in $40-\mathrm{mL}$ flasks, placed in isothermal boxes with ice, and transported to the Laboratory of Milk Quality of the Food Research Center located in the Veterinary and Animal Science School of the Federal University of Goiás.

Milk $\mathrm{pH}$ was determined in triplicate with the use of a digital potentiometer model W38 (Bel Engineering $\left.{ }^{\circledR}\right)$. The titratable acidity of milk samples was also determined in triplicate using phenolphthalein as an indicator and 0.1 molar sodium hydroxide $(\mathrm{NaOH})$ solution, according to the methodology of Instituto Adolfo Lutz (2008).

\section{Formulation of natural yogurts}

Treatments consisted of refrigerated milk (treatment 1), pasteurized milk (treatment 2), and UHT milk (treatment 3). In treatments 1 and 3, raw and pasteurized milk, respectively, were heated at $42{ }^{\circ} \mathrm{C}$ and the lyophilized culture BioRich ${ }^{\circledR}$ containing L. acidophilus, Bifidobacterium, and $S$. thermophilus at a rate of $400 \mathrm{mg} / \mathrm{L}$ was added. In treatment 2 , raw refrigerated milk was pasteurized at $90^{\circ} \mathrm{C}$ for 3 minutes and cooled at $42{ }^{\circ} \mathrm{C}$ in order to inoculate the lyophilized culture cited above.

Yogurts were packed in glass pots and incubated in an oven at $42{ }^{\circ} \mathrm{C}$ until reaching a $\mathrm{pH}$ of 4.6. After fermentation, the yogurt was cooled in a water and ice bath until reaching a temperature of $10^{\circ} \mathrm{C}$, being the clot broken using a glass stick in circular movements until a complete homogenization. Subsequently, $\pm 240 \mathrm{~g}$ of yogurts were packed into 250-mL capacity polypropylene containers for each treatment and conditioned under refrigeration at 5 ${ }^{\circ} \mathrm{C}$ for 24 hours, followed by physicochemical and rheological analyses.

\section{Assessment of $p H$}

A digital potentiometer model W38 (Bel Engineering $^{\circledR}$ ) was used for $\mathrm{pH}$ assessment. For reading, the electrode was placed in the sample without touching the bottom and sides of the package (IAL, 2008).

\section{Assessment of titratable acidity}

Titratable acidity was determined in triplicates according to the methodology described by Instituto Adolfo Lutz (2008), which consisted of the titration of $10 \mathrm{~g}$ of yogurt sample with 0.1 molar sodium 
hydroxide $(\mathrm{NaOH})$ solution and phenolphthalein (three drops) as an indicator. The results were expressed as a percentage of lactic acid.

\section{Syneresis}

For syneresis determination, $30 \mathrm{~g}$ of yogurt were distributed on filter paper placed on the top of a funnel. After five hours of drainage, the fluid volume was collected and the syneresis index was calculated according to the following equation (RIENER et al., 2010): Syneresis $=$ (weight of serum after filtration $\div$ weight of yogurt sample) $\times 100$.

\section{Viscosity}

The apparent viscosity was determined on a Quimis $^{\circledR}$ microprocessor rotational viscometer model Q860M26. Samples were positioned at the correct height of the spindle No. 3 at a speed of 48 $\mathrm{rpm}$. The minimum reading time was approximately five minutes per sample and the results were expressed in MPa.s (megapascal.second).

\section{Microbiological analyses \\ Counting of viable lactic bacteria}

An aliquot of $25 \mathrm{~g}$ of yogurt was diluted in 225 $\mathrm{mL}$ sterile peptone water. Serial dilutions followed by plating in depth on MRS (Man Rogosa \& Sharpe) agar and incubation at $35^{\circ} \mathrm{C}$ for $48 \mathrm{~h}$ were performed. The results were expressed in colony forming units per $\mathrm{g}$ (CFU/g) (MACEDO, 1997).

\section{Counting of total coliforms and coliforms at $45^{\circ} \mathrm{C}$}

Aliquots of $1 \mathrm{~mL}$ of $10^{-1}, 10^{-2}$, and $10^{-3}$ concentrations were transferred to test tubes containing $10 \mathrm{~mL}$ lauryl sulfate (LST) broth with Durham tubes, which were incubated at $35{ }^{\circ} \mathrm{C}$ for 24 hours. For the total coliforms test, from the LST tubes that showed growth and gas production, an inoculation loop with culture was transferred into brilliant green bile broth tubes with Durham tubes, which were subsequently incubated at $35^{\circ} \mathrm{C}$ for 24 hours. Gas production confirmed the presence of total coliforms.

For the coliform at $45^{\circ} \mathbf{C}$ test, an inoculation loop with culture was transferred from the LST broth to E. coli (EC) broth with Durham tubes. Tubes were incubated for 24 hours in a water bath at $45^{\circ} \mathbf{C}$. After this time, no gas and turbidity were observed in the tubes.

\section{Fat}

Fat content was determined by the Gerber butyrometric method (BRASIL, 2006). This method consists of adding $10 \mathrm{~mL}$ sulfuric acid, $11 \mathrm{~mL}$ of sample, and $1 \mathrm{~mL}$ isoamyl alcohol PA (98.5\%) into the butyrometer, shaking until complete dissolution, and centrifuging for 5 minutes. The results were expressed in percentage.

\section{Protein}

Protein analyses were performed based on the determination of nitrogen by the Kjeldahl method. Protein content was calculated by multiplying the nitrogen value by 6.38 (BRASIL, 2006).

\section{Moisture}

Yogurt samples were conditioned in an oven at $105^{\circ} \mathbf{C}$ until constant weight (BRASIL, 2006).

\section{Color}

Color instrumental parameters $\left(\mathrm{L}, \mathrm{a}^{*}\right.$, and $\left.\mathrm{b}^{*}\right)$ of natural yogurts were determined in a Hunter Lab colorimeter model Color Quest (HUNTERLAB, 1998). 


\section{Lyophilization of yogurts}

Yogurts were submitted to the lyophilization process on the 8th day after storage. Samples were placed in glass bottles, submitted to quick freeze in an ultra-freezer (Terroni $\left.{ }^{\circledR}\right)$ at $-80^{\circ} \mathrm{C}$, and subsequently lyophilized in a lyophilizer (Enterprise II/Terroni ${ }^{\circledR}$ ). Lyophilized yogurts were stored in identified glass pots with lid and stored in a freezer to avoid moisture absorption.

\section{Reconstitution of lyophilized yogurts}

Lyophilized yogurts were reconstituted in filtered and pasteurized water at $35^{\circ} \mathbf{C}$ after 22 days of storage, being stored under refrigeration at $\pm 5^{\circ} \mathrm{C}$ for 24 hours. Reconstitution was performed according to the total solids present in the in natura yogurt prior to lyophilization following the rates of $11.21,11.51$, and $11.99 \%$ for refrigerated, pasteurized, and UHT, respectively. After reconstitution, physicochemical, lactic bacteria counting, and viscosity analyses were performed.

\section{Scanning electron microscopy (SEM)}

Lyophilized yogurts were defatted by the Soxhlet method, stored in plastic containers, conditioned in a desiccator with silica gel, and transported to the Laboratory of Electron Microscopy (LabMic) of the Federal University of Goiás. Samples were assembled in stubs and covered with gold for metallization. Subsequently, the stubs were examined under a scanning electron microscope (JSM-6610/Jeol ${ }^{\circledR}$ ).

\section{Statistical analyses}

The average results of the physicochemical composition of milk and natural and reconstituted yogurts were compared by the Tukey's test at $5 \%$ probability by using the software SISVAR (FERREIRA, 2008). The average values of $\mathrm{pH}$, titratable acidity, syneresis, viscosity, and viable lactic bacteria during the 29 days of storage were presented by means of regression (Excel).

\section{Results and Discussion}

Table 1 shows the physicochemical results of raw material used for processing the natural yogurts. Fat values differed significantly $(p<0.05)$ only in refrigerated milk. Protein contents varied only in pasteurized milk. However, all treatments met the requirements of the milk quality legislation since according to the Brazilian legislation (BRASIL, 2011) milk should contain at least $3 \%$ fat and $2.9 \%$ protein.

Table 1. Physicochemical characteristics of milk under different heat treatments.

\begin{tabular}{ccccc}
\hline \multirow{2}{*}{ Parameter } & \multicolumn{3}{c}{ Heat treatment } & \multirow{2}{*}{ CV (\%) } \\
\cline { 2 - 4 } & Refrigerated & Pasteurized & UHT & 1.98 \\
Fat (\%) & $3.12 \pm 0.07 \mathrm{a}$ & $3.04 \pm 0.06 \mathrm{~b}$ & $3.09 \pm 0.05 \mathrm{~b}$ & 1.15 \\
Protein (\%) & $3.30 \pm 0.01 \mathrm{~b}$ & $3.57 \pm 0.07 \mathrm{a}$ & $3.25 \pm 0.01 \mathrm{~b}$ & 1.14 \\
Lactose (\%) & $4.45 \pm 0.016 \mathrm{~b}$ & $4.97 \pm 0.01 \mathrm{a}$ & $4.36 \pm 0.08 \mathrm{~b}$ & 1.01 \\
DDE (\%) & $8.56 \pm 0.01 \mathrm{~b}$ & $9.50 \pm 0.02 \mathrm{a}$ & $8.70 \pm 0.15 \mathrm{~b}$ & 0.60 \\
pH & $6.73 \pm 0.03 \mathrm{a}$ & $6.72 \pm 0.05 \mathrm{a}$ & $6.74 \pm 0.03 \mathrm{a}$ & 4.93 \\
\hline Acidity (g lactic acid/100 mL) & $0.14 \pm 0.01 \mathrm{a}$ & $0.14 \pm 0.01 \mathrm{a}$ & $0.14 \pm 0.01 \mathrm{a}$ \\
\hline
\end{tabular}

Equal lowercase letters in the same line do not differ from each other by the Tukey's test at 5\% probability level. 
The values of $\mathrm{pH}$ and titratable acidity had no significant variation $(p>0.05)$ between treatments. Titratable acidity is in accordance with the legislation, which recommends values between 0.14 to $0.18 \mathrm{~g}$ lactic acid $/ 100 \mathrm{~mL}$. The values of refrigerated and pasteurized milk were similar to those found by Silva et al. (2010), who found values of $3.31 \%$ and $3.38 \%$ for fat, $3.33 \%$ to $3.30 \%$ for protein, $4.45 \%$ and $4.41 \%$ for lactose, and $8.66 \%$ and $8.64 \%$ for DDE, respectively for raw refrigerated and pasteurized milk. Likewise, Souza et al. (2004) observed values of $3.32 \%$ for fat, $3.16 \%$ for protein, $4.47 \%$ for lactose, and $8.66 \%$ for DDE in UHT milk.

Figure 1 shows the $\mathrm{pH}$ kinetics during yogurt fermentation until obtaining a $\mathrm{pH}$ of \pm 4 .6, which promotes precipitation of caseins with consequent gel formation. Incubation time to reach a $\mathrm{pH}$ of 4.6 was 460 minutes for yogurts produced with pasteurized milk and UHT, and 280 minutes for that produced with refrigerated milk. Silva et al. (2012) assessed the natural yogurt fermentation kinetics using UHT milk and obtained faster fermentations, which required only 120 minutes to reach a $\mathrm{pH}$ of 4.71 .

Figure 2 shows the $\mathrm{pH}$ behavior on the $1^{\text {st }}, 8^{\text {th }}$, $15^{\text {th }}, 22^{\text {nd }}$, and $29^{\text {th }}$ days of storage. During the 29 days of yogurt storage, the $\mathrm{pH}$ decreased, being inversely proportional to the titratable acidity. The final $\mathrm{pH}$ values were 4.02, 4.03, and 4.04 for yogurts produced with refrigerated, pasteurized, and UHT milk, respectively. The decrease in $\mathrm{pH}$ during the storage period is related to lactose degradation promoted by microorganisms. According to Gallina et al. (2011), yogurts are subject to a decrease in $\mathrm{pH}$ and an increase in acidity during refrigerated storage due to bacteria activity, which consume lactose and produce lactic acid.

Figure 1. The pH kinetics for yogurts obtained from refrigerated, pasteurized, and ultra-high temperature (UHT) milk during fermentation.

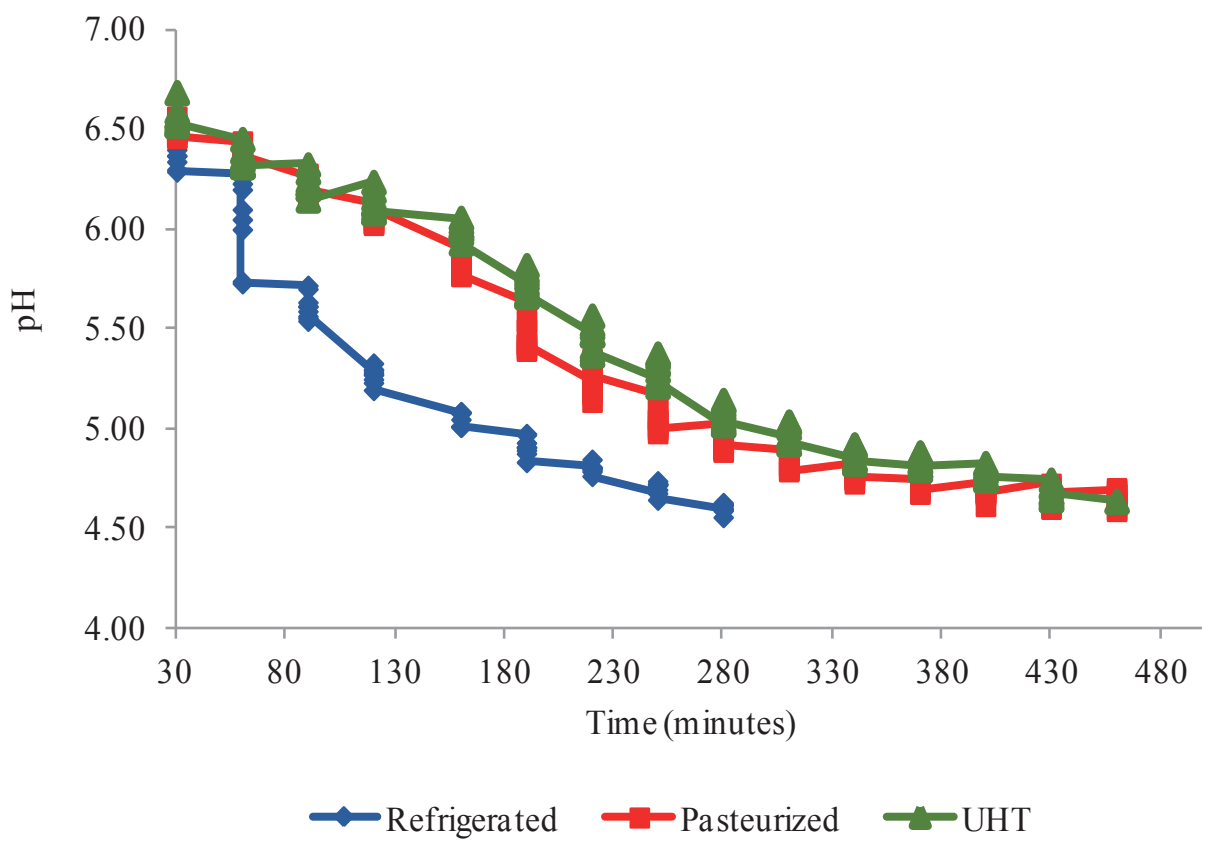


Figure 2. The $\mathrm{pH}$ of yogurts obtained from refrigerated, pasteurized, and ultra-high temperature (UHT) milk during storage.

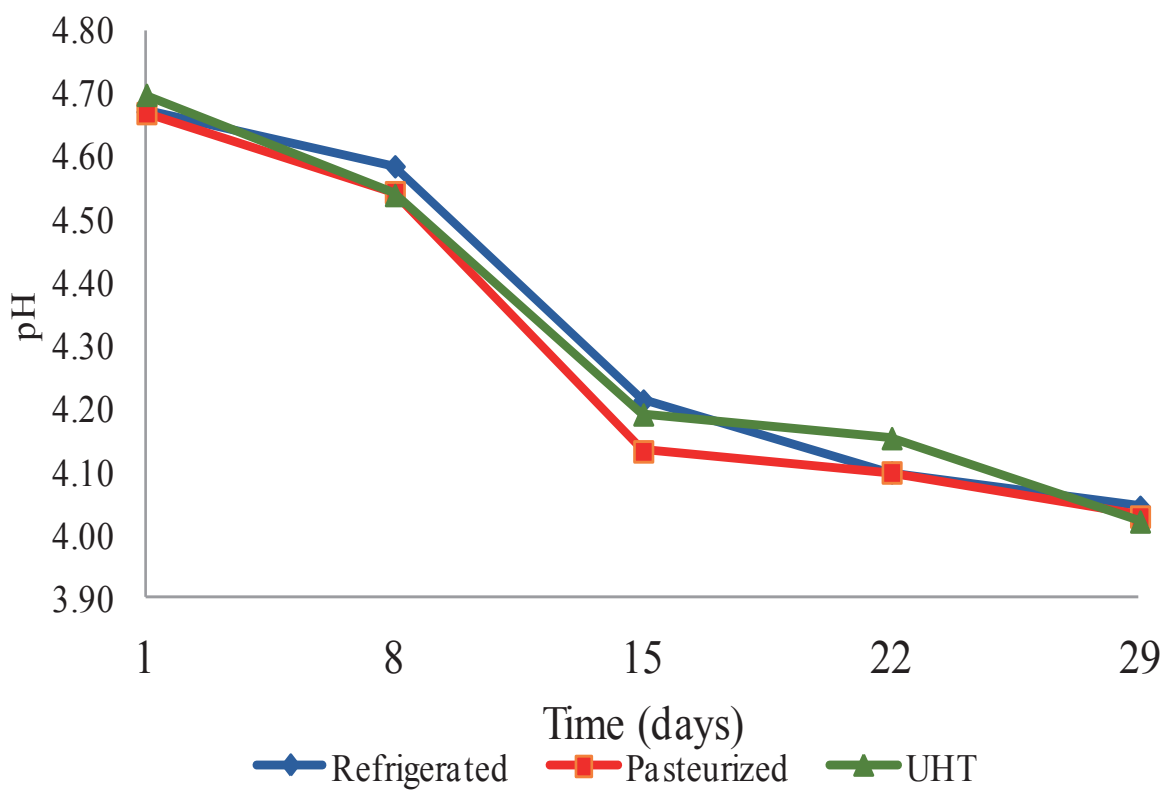

Figure 3 shows the titratable acidity behavior over the 29 days of storage. Acidity values ranged from 0.75 to $1.00 \%$ and are in accordance with those established by legislation, i.e. 0.6 to $1.5 \%$ lactic acid. In a study with yogurts supplemented with soybean, Hauly et al. (2005) obtained increasing values of acidity over the storage period. Longo et al. (2006) reported values similar to those found in our study.

Figure 3. Titratable acidity of yogurts obtained from refrigerated, pasteurized, and ultra-high temperature (UHT) milk during storage.

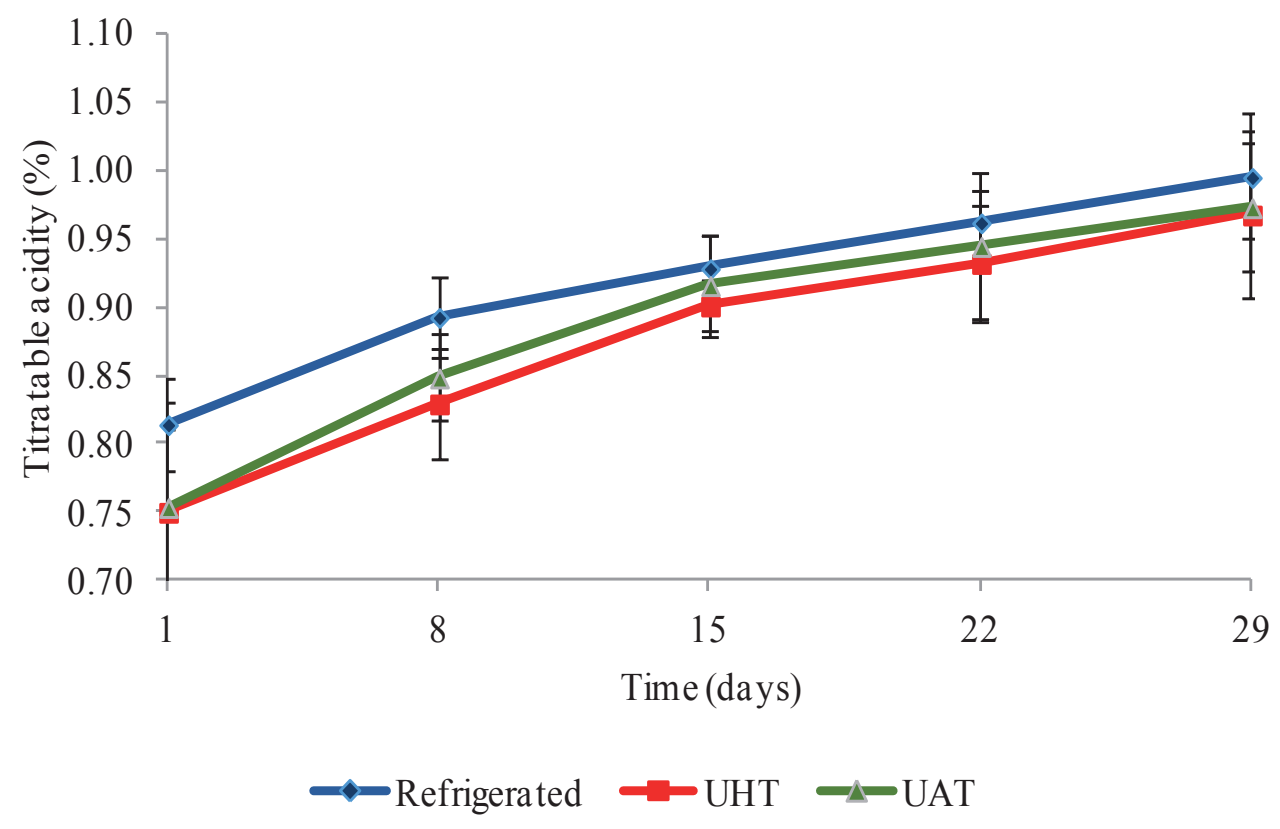


Figure 4 shows the syneresis behavior over decreased values in storage times and a gradual the storage period of natural yogurts. Syneresis increase in its values only in the period from the presented similar behavior for all treatments, with 22 nd to the 29 th day.

Figure 4. Syneresis of yogurts obtained from refrigerated, pasteurized, and ultra-high temperature (UHT) milk during storage.

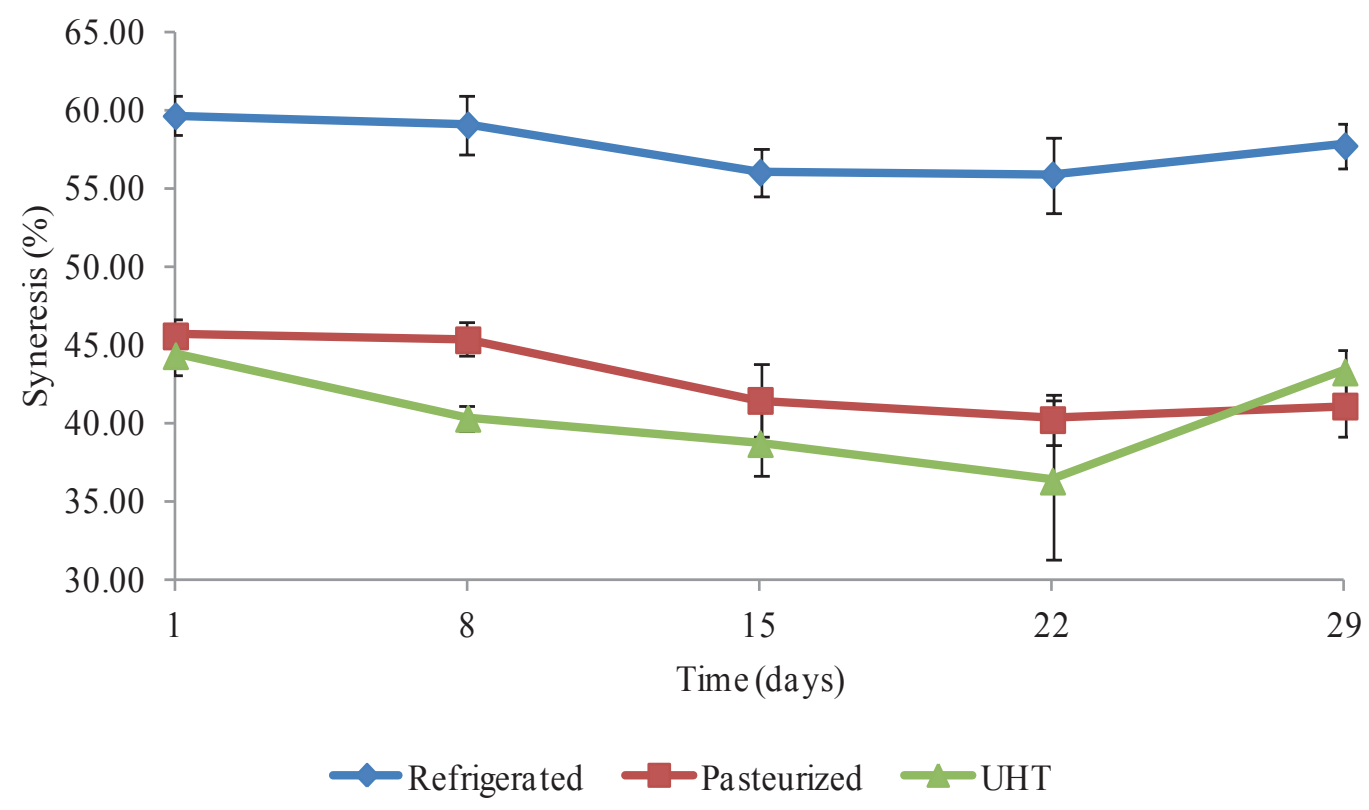

The yogurt produced without heat treatment of milk had a greater tendency to syneresis when compared to the treatments submitted to heat. Medeiros et al. (2010) studied the effect of heat treatment and incubation temperature on the syneresis effect on yogurts and found that unheated yogurts showed a greater tendency to syneresis due to gel contraction and concomitant serum expulsion. This result is similar to that found in our study.

Studies have shown the temperature dependence in gel formation process by means of values of casein micelles aggregation, which may be influenced by hydrophobic interactions since they are favored by high temperatures, achieving a higher structural rigidity (VÉTIER et al., 2003).

Figure 5 shows the viscosity behavior of natural yogurts during the 29 days of storage. The apparent viscosity value of natural yogurts increased from the $1^{\text {st }}$ to the $22^{\text {nd }}$ day of storage whereas from the $22^{\text {nd }}$ to the $29^{\text {th }}$ day its value reduced. However, Silva et al. (2012) assessed the kinetic and rheological behavior of lactic fermentation for natural yogurt production and observed that the yogurt presented non-Newtonian fluid behavior (pseudo-plastic), in which the viscosity decreased as the strain rate increased. Cunha Neto et al. (2005), on the other hand, assessed the natural yogurt obtained from buffalo milk with different fat levels, and with no differences in viscosity values for different treatments at 1,15 , and 30 days of storage. In this case, the reduction in fat content of buffalo milk had no influence on natural yogurt viscosity, disregarding an increase in the total solids content of milk to preserve the physical characteristics of yogurt. 
Figure 5. Viscosity of yogurts obtained from refrigerated, pasteurized, and ultra-high temperature (UHT) milk during storage.

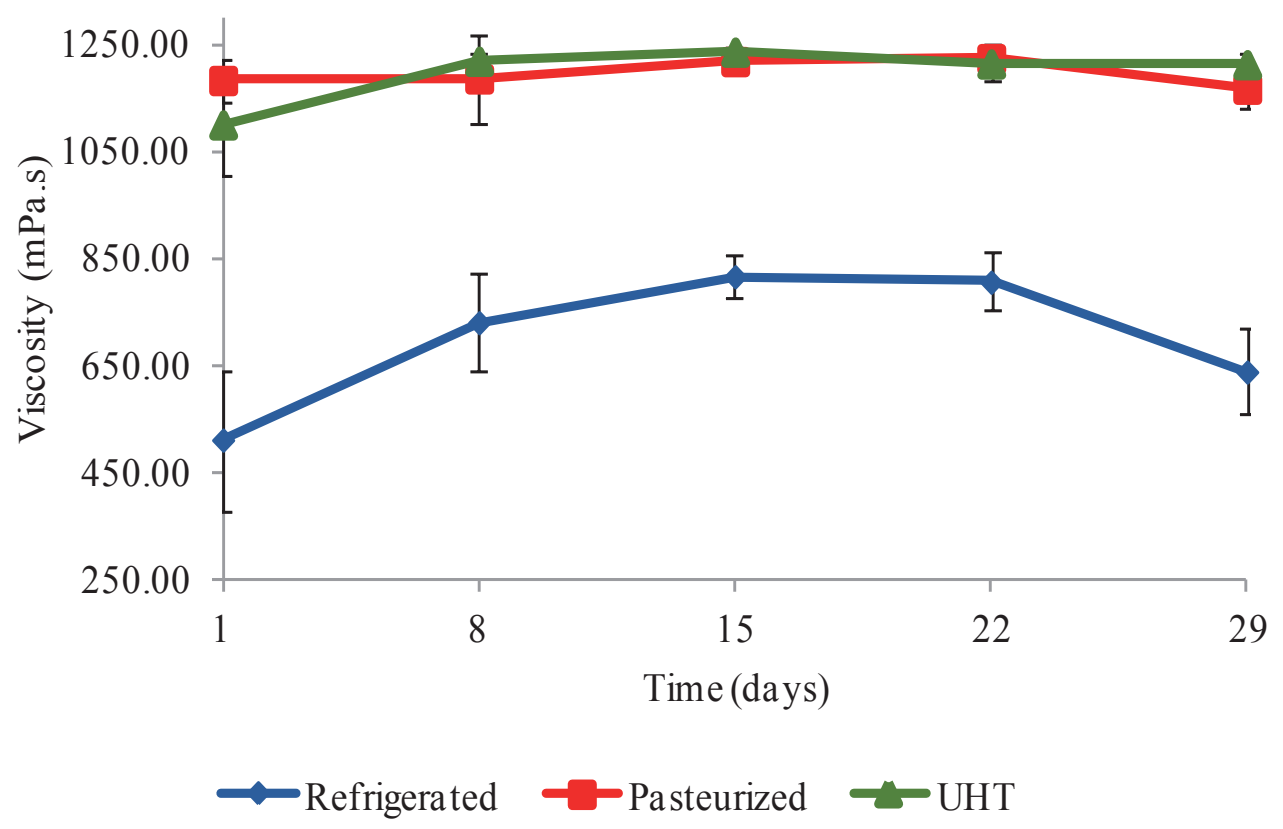

The apparent viscosity of a product significantly influences the consumer's acceptance and purchase intention, being, therefore, an important factor that must be controlled during yogurt processing. Consistency and viscosity are factors that influence mainly final product quality, consequently exerting a great influence on its acceptance (MATHIAS et al., 2013).

Figure 6 shows the results of lactic bacteria over the 29 days of storage. During the storage period, lactic bacteria decreased from the 8th to 15 th day for the yogurt produced with raw refrigerated milk, with viable lactic bacteria counting below $10^{4} \mathrm{CFU} /$ $\mathrm{mL}$ whereas the other treatments were viable until the 15th day of storage. Between the 22nd and 29th day of storage, all treatments presented counting below $10^{4} \mathrm{CFU} / \mathrm{mL}$, which is out of the standards established by the current legislation on identity and quality standards of fermented milk (BRASIL, 2007). 
Figure 6. Viable lactic bacteria counting of yogurts obtained from refrigerated, pasteurized, and ultra-high temperature (UHT) milk during storage.

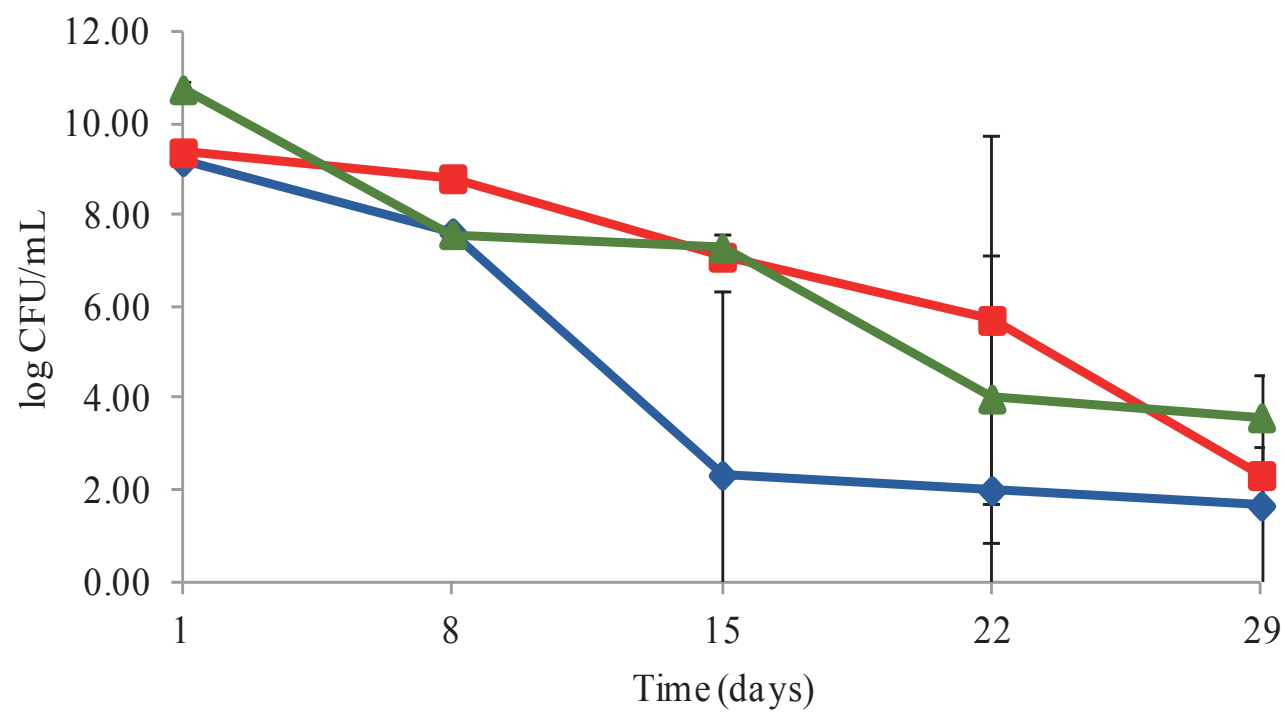

$\rightarrow$-Refrigerated $\rightarrow$ Pasteurized

According to Thamer and Penna (2005), a $\mathrm{pH}$ below the ideal interferes with the viability of probiotic colonies in the food, thus reducing the viable Lactobacillus cell counting. Shah (2000) reported that, in addition to the acidity produced during the storage period, the exchange of oxygen between packaging and the atmosphere influences lactic bacteria life, being the sensitivity to substances produced by yogurt bacteria and the lack of nutrient the factors responsible for the loss of viability of probiotic microorganisms. Sales et al. (2007) emphasized the importance of the storage temperature or yogurt conditioning on changes in product microbiological conditions, which occur both in industries and in commercial establishments. Because no heat treatment was applied in treatment 1, certainly a competition occurred between unknown microorganisms and the lactic culture, thus reducing the beneficial bacteria and hence the life of yeast microorganisms.
Capitani et al. (2014) assessed the characteristics of yogurts obtained using probiotic cultures from Lactobacillus acidophilus, and Bifidobacterium spp. and a prebiotic fiber (polydextrose) and found values of viable lactic bacteria counting higher than $10^{8} \mathrm{CFU} / \mathrm{mL}$ on the 14 th day of storage, which is a value higher when compared to that obtained in our study.

Microbiological analyses carried out during the 29 days of storage evidenced an absence of total coliforms and coliforms at $45^{\circ} \mathbf{C}$. Forsythe (2002) reported that the absence of coliforms in the final product could also be an indicative of good hygienicsanitary conditions during the manufacturing process of yogurts.

Table 2 shows the physicochemical values of yogurts produced with different heat treatments. Heat treatments of milk during natural yogurt manufacturing showed no significant difference by the Tukey's test at $5 \%$ probability for fat and protein. 
Table 2. Average values of fat, protein, moisture, titratable acidity, and $\mathrm{pH}$ of yogurts produced with different heat treatments.

\begin{tabular}{ccccc}
\hline \multirow{2}{*}{ Parameter } & \multicolumn{3}{c}{ Heat treatment } & \multirow{2}{*}{ CV (\%) } \\
\cline { 2 - 4 } & Refrigerated & Pasteurized & UHT & \\
\hline Fat (\%) & $2.77 \pm 0.05 \mathrm{a}$ & $2.74 \pm 0.07 \mathrm{a}$ & $2.74 \pm 0.07 \mathrm{a}$ & 2.40 \\
Protein (\%) & $2.73 \pm 0.60 \mathrm{a}$ & $2.74 \pm 0.57 \mathrm{a}$ & $2.45 \pm 0.52 \mathrm{a}$ & 21.74 \\
Moisture (\%) & $88.70 \pm 0.1 \mathrm{a}$ & & $88.01 \pm 0.2 \mathrm{c}$ & 0.15 \\
Acidity (g lactic acid/100 g) & $0.89 \pm 0.03 \mathrm{a}$ & $0.83 \pm 0.04 \mathrm{~b}$ & $0.85 \pm 0.03 \mathrm{~b}$ & 3.98 \\
pH & $4.57 \pm 0.04 \mathrm{a}$ & $4.55 \pm 0.02 \mathrm{~b}$ & $4.54 \pm 0.02 \mathrm{~b}$ & 0.61 \\
\hline
\end{tabular}

Equal lowercase letters in the same line do not differ from each other by the Tukey's test at 5\% probability level.

Moisture showed a significant difference $(\mathrm{p}<0.05)$ between treatments, showing decreased values as time and temperature increased in the different heat treatments. The refrigerated yogurt presented a higher moisture content as no heat treatment was applied, besides heating up to $42{ }^{\circ} \mathrm{C}$. On the other hand, yogurts produced with pasteurized and UHT milk showed a decrease in moisture contend due to heat treatment, with water evaporation.

The values of $\mathrm{pH}$ and acidity presented a significant difference $(p<0.05)$ only for yogurt produced from refrigerated milk without heat treatment, with higher $\mathrm{pH}$ and acidity values when compared to the other treatments. According to the Normative Instruction No. 46/2007 (BRASIL, 2007), yogurt acidity is within the parameters established by the current legislation ( 0.6 to $1.5 \%)$.

Physicochemical values of yogurts allowed them to be classified as partially skimmed since they presented fat contents between 0.6 and 2.9\% and protein values below the value established by the legislation of at least $2.9 \%$.

Table 3 shows the parameters color and viscosity of lyophilized and reconstituted yogurts. Luminosity $\left(\mathrm{L}^{*}\right)$ for both lyophilized and reconstituted yogurts produced from UHT milk presented higher values in relation to yogurts produced with refrigerated and pasteurized milk. The luminosity of UHT milk is related to the manufacturing process in which the milk is homogenized, leading to fat molecules break down into small parts and causing the globules to become homogeneous (CUNHA, 2001).

Table 3. Average values of color and viscosity of lyophilized and reconstituted yogurts obtained from refrigerated, pasteurized, and ultra-high temperature (UHT) milk.

\begin{tabular}{llcccc}
\hline \multirow{2}{*}{ Parameter } & & \multicolumn{3}{c}{ Heat treatment } & \multirow{2}{*}{ CV (\%) } \\
\cline { 3 - 5 } Lyophilized & $\mathrm{L}^{*}$ & $90.78 \pm 0.54 \mathrm{c}$ & $91.32 \pm 0.12 \mathrm{~b}$ & $92.51 \pm 0.14 \mathrm{a}$ & 0.36 \\
& $\mathrm{a}^{*}$ & $-0.28 \pm 0.03 \mathrm{a}$ & $-0.19 \pm 0.01 \mathrm{~b}$ & $-0.16 \pm 0.03 \mathrm{~b}$ & 12.77 \\
& $\mathrm{~b}^{*}$ & $15.16 \pm 0.27 \mathrm{a}$ & $13.45 \pm 0.17 \mathrm{~b}$ & $12.16 \pm 0.18 \mathrm{c}$ & 1.58 \\
\hline \multirow{3}{*}{ Reconstituted } & $\mathrm{L}^{*}$ & $88.33 \pm 0.03 \mathrm{c}$ & $88.85 \pm 0.06 \mathrm{~b}$ & $89.41 \pm 0.01 \mathrm{a}$ & 0.04 \\
& $\mathrm{a}^{*}$ & $-1.05 \pm 0.03 \mathrm{a}$ & $-0.96 \pm 0.02 \mathrm{~b}$ & $-0.59 \pm 0.03 \mathrm{c}$ & 3.12 \\
& $\mathrm{~b}^{*}$ & $12.88 \pm 0.09 \mathrm{a}$ & $12.18 \pm 0.08 \mathrm{~b}$ & $12.18 \pm 0.01 \mathrm{~b}$ & 0.56 \\
\hline Viscosity (MPa.s) & & $192.611 \pm 1.30 \mathrm{c}$ & $264.167 \pm 44.33 \mathrm{~b}$ & $422.5 \pm 35.20 \mathrm{a}$ & 11.06 \\
\hline
\end{tabular}

Equal lowercase letters in the same line do not differ from each other by the Tukey's test at $5 \%$ probability level. 
The negative value $\left(-\mathrm{a}^{*}\right)$ goes toward the green whereas the positive value $\left(\mathrm{a}^{*}\right)$ goes toward the red. Thus, significant differences $(p<0.05)$ were observed between treatments, all of them tending to green color. The yogurt obtained from refrigerated milk was the one that came closest to the greenish color, differing from the other treatments. On the other hand, the negative value $\left(-b^{*}\right)$ goes toward blue whereas the positive value $\left(b^{*}\right)$ goes towards yellow. All treatments tended to yellow, in accordance to what was reported by Behmer (1999), who observed the milk color as a slightly yellowish white emulsion, thus confirming the results found in our study.
Regarding the viscosity, the absence of heat treatment in milk for yogurt production led to lower viscosity values when compared to those observed in other treatments. In addition, the results showed no significant difference $(p>0.05)$ between treatments regarding the parameters fat, protein, and $\mathrm{pH}$.

Table 4 shows the physicochemical results of natural yogurts produced from different heat treatments. Reconstituted yogurts presented fat contents between 0.6 and 2.9\%, which, according to the Normative Instruction No. 46/2007 (BRASIL, 2007), allows them to be classified as semi-skimmed yogurts.

Table 4. Physicochemical values and viable lactic cells of natural yogurts after reconstitution.

\begin{tabular}{lcccc}
\hline \multirow{2}{*}{ Parameter } & \multicolumn{3}{c}{ Heat treatment } & \multirow{2}{*}{ CV (\%) } \\
\cline { 2 - 4 } & Refrigerated & Pasteurized & UHT & \\
\hline Fat (\%) & $2.76 \pm 0.13 \mathrm{a}$ & $2.73 \pm 0.05 \mathrm{a}$ & $2.74 \pm 0.07^{\mathrm{a}}$ & 3.36 \\
Protein (\%) & $2.73 \pm 0.30 \mathrm{a}$ & $2.74 \pm 0.70 \mathrm{a}$ & $2.45 \pm 0.19^{\mathrm{a}}$ & 17.35 \\
Moisture (\%) & $88.80 \pm 0.10 \mathrm{a}$ & $88.49 \pm 0.1 \mathrm{ab}$ & $88.06 \pm 0.78 \mathrm{~b}$ & 0.53 \\
Acidity (g lactic acid/100 g) & $0.98 \pm 0.01 \mathrm{a}$ & $0.97 \pm 0.02 \mathrm{a}$ & $0.80 \pm 0.03 \mathrm{~b}$ & 2.58 \\
$\mathrm{pH}$ & $4.02 \pm 0.08 \mathrm{a}$ & $4.03 \pm 0.05 \mathrm{a}$ & $4.07 \pm 0.06^{\mathrm{a}}$ & 1.51 \\
Viable lactic cells (CFU/mL) & $9.33 \times 10^{4} \pm 4.04 \times 10^{3} \mathrm{~b}$ & $3 \times 10^{5} \pm 5.77 \times 10^{3} \mathrm{a}$ & $5.33 \times 10^{5} \pm 1.53 \times 10^{3} \mathrm{a}$ & 29.53 \\
\hline
\end{tabular}

Equal lowercase letters in the same line do not differ from each other by the Tukey's test at $5 \%$ probability level.

Protein content was below the minimum limit established by the current legislation, i.e. $2.9 \%$. These results are in accordance with those found by Cunha et al. (2008), who reported a protein content of $2.80 \%$ in yogurts in which Lactobacillus acidophilus, Bifidobacterium, and Streptococcus thermophilus were added.

Titratable acidity results presented lower values when compared to those found by Pimentel et al. (2012), with values between 1.11 and $1.17 \mathrm{~g}$ lactic acid/100 g. However, the results obtained are in accordance with the current legislation, which recommends values between 0.6 and $1.5 \mathrm{~g}$ lactic acid/100 g. The viable lactic bacteria had no minimum value according to the legislation, which recommends a minimum of $10^{7} \mathrm{CFU} / \mathrm{mL}$. Therefore, lyophilization preserved the physicochemical characteristics of yogurts but did not preserve the viability of viable lactic bacteria.

Figure 7 (A, B, and C) shows the scanning electron microscopy images in lyophilized yogurts produced with refrigerated, pasteurized, and UHT milk. At 30-x magnification, particles of irregular and pointed shapes covered by recesses and protrusions were found, without a smooth and homogeneous surface. At 1000-x magnification, the microstructure of yogurts was observed with several empty spaces in the protein matrix, indicating the initial presence of fat particles extracted from the sample during its preparation for analysis. In the UHT yogurt, smaller empty spaces were observed when compared to the other treatments due to 
UHT milk homogenization process, during which fat globules are broken down into smaller sizes, leading to smaller empty spaces. Finally, at 5000-x and 10000-x magnification, casein networks were observed in each treatment. In the treatment UHT, live forms of rod-shaped bacteria (Lactobacillus) were found.

Figure 7. Scanning electron microscopy of yogurts produced with refrigerated, pasteurized, and UHT milk.
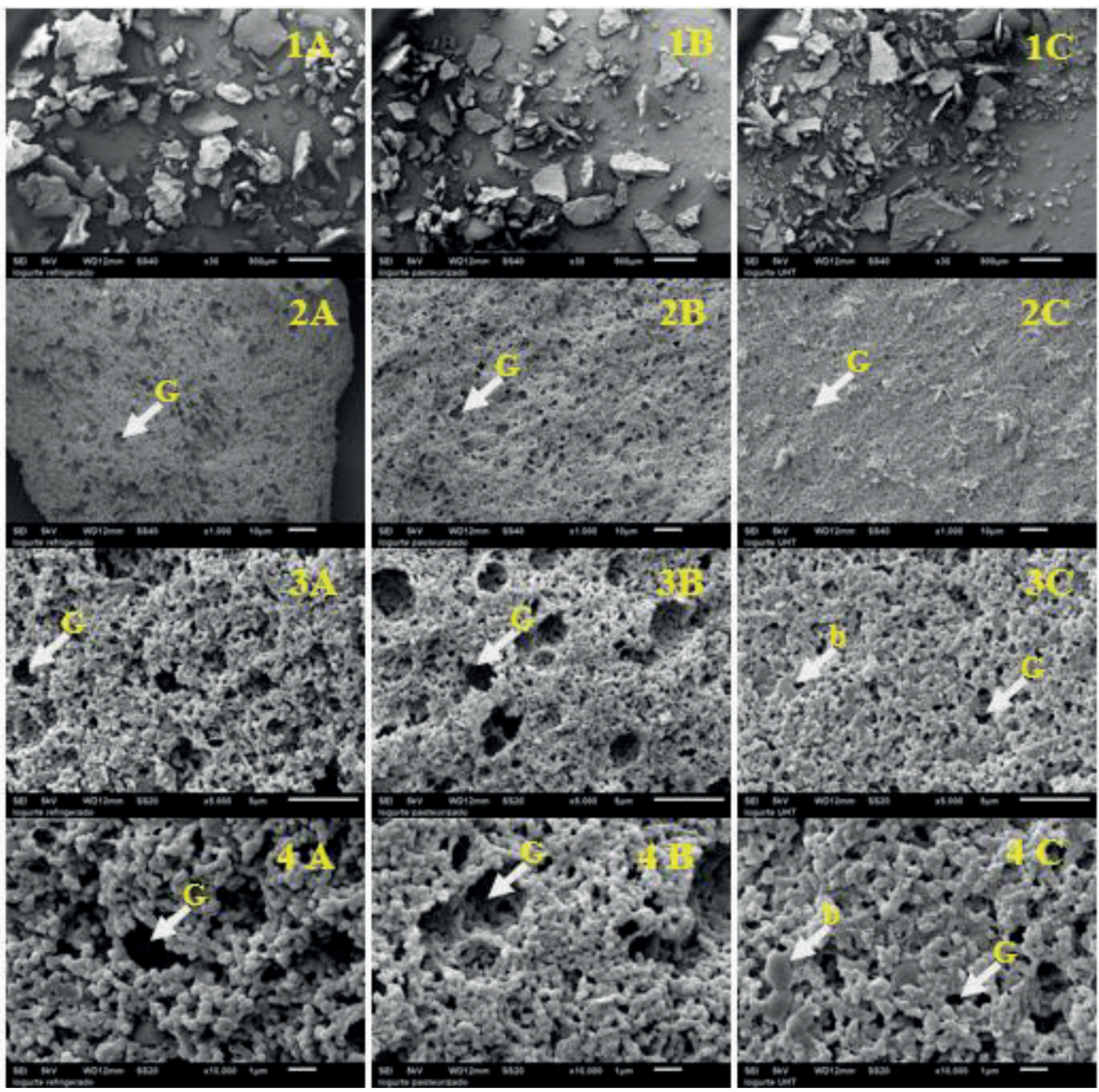

Magnification: $1=30-\mathrm{x}, 2=1000-\mathrm{x}, 3=5000-\mathrm{x}$, and $4=10000-\mathrm{x}$. A = yogurt produced with refrigerated milk, $\mathrm{B}=$ yogurt produced with pasteurized milk, and $\mathrm{C}=$ yogurt produced with UHT milk. $\mathrm{G}=$ empty space where the fat globule was found and $\mathrm{b}=$ bacilli. 


\section{Conclusion}

Raw material physicochemical characteristics are in accordance with the Brazilian legislation. The yogurt without heat treatment presented a shorter fermentation time when compared to the other treatments, which may be related to natural bacteria present in the milk, reaching a $\mathrm{pH}$ of 4.6 in a time of 280 minutes.

The $\mathrm{pH}$ value presented a tendency of decreasing whereas the titratable acidity presented a tendency of increasing over the 29 days of storage. The yogurt produced with refrigerated milk presented higher acidity from the $1^{\text {st }}$ to the $29^{\text {th }}$ day of storage. Heat treatment positively influenced syneresis and viscosity, being the refrigerated yogurt more susceptible to syneresis and lower viscosity. Lactic bacteria were only viable on the 15 th day, except for refrigerated yogurt. Physicochemical characteristics of natural yogurts do not meet the Brazilian Normative Instruction 46/2007, except for protein content. Yogurt lyophilization was effective, maintaining the original physicochemical characteristics after yogurt reconstitution. The scanning electron microstructure analysis of natural yogurts provided the visualization of live forms (rods) of lactobacilli only in UHT yogurt.

\section{Acknowledgements}

To FAPEG(Goiás Research Foundation), CAPES (Coordination for the Improvement of Higher Education Personnel), CNPq (National Council for Scientific and Technological Development), and FINEP(Funding Authority for Studies and Projects).

\section{References}

ARASHIRO, E. K. N.; TEODORO, V. A. M.; MIGUEL, E. M. Revista do Instituto de Laticínios Cândido Tostes, v. 61, n. 352, p. 32-36, 2006.

BEHMER, M. L. A. Tecnologia do leite. 13. ed. São Paulo: Nobel, 1999. 320 p.
BRASIL. Instrução Normativa $\mathrm{n}^{\circ}$ 62, de 29 de dezembro de 2011. Aprovar o Regulamento Técnico de Produção, Identidade e Qualidade do Leite tipo A o da Coleta de Leite Cru Refrigerado e seu Transporte a Granel. Diário Oficial [da] União. Regulamento técnico de identidade e qualidade de leite cru refrigerado, o regulamento técnico de identidade e qualidade de leite pasteurizado e o regulamento técnico República Federativa do Brasil, Brasília, 30 dez. 2011. Seção 1, p. 1-24.

Ministério da Agricultura, Pecuária e Abastecimento. Departamento de Inspeção de Produtos de Origem Animal. Instrução Normativa $n^{\circ} .46$. Regulamento técnico de identidade e qualidade de leites fermentados. Diário Oficial [da] União, Brasília, 24 out. 2007, Seção 1, p. 5.

Ministério da Agricultura, Pecuária e Abastecimento. Instrução Normativa $n^{0} 68$, de 12 de dezembro de 2006. Métodos analíticos oficiais físicoquímicos para $0 \%$ de leite e produtos lácteos (revoga Instrução Normativa $\mathrm{n}^{\circ} 22$, de 14 de abril de 2003). Diário Oficial [da] União. Brasília, 14 dez. 2006. Seção 1, p. 8.

CAPITANI, C.; HAUSCHILD, F. A. D. H.; FRIEDRICH, C. J.; LEHN, D. N. Caracterização de iogurtes elaborados com probióticos e fibra solúvel. Revista Brasileira de Tecnologia Agroindustrial, v. 8, n. 2, p. 1285-1300, 2014.

CUNHA NETO, O. C. da; OLIVEIRA, C. A. F. de; HOTTA, R. M.; FRANZOLIN NETO, R. Estudo da qualidade do iogurte natural batido produzido com leite de búfala contendo diferentes níveis de gordura. Ciência e Tecnologia de Alimentos, Campinas, v. 25, n. 3, p. 448$453,2005$.

CUNHA, M. F. Leite UHT e o fenômeno de gelatinização. Boletim do Centro de Pesquisa de Processamento de Alimentos, v. 19, n. 2, p. 341-352, 2001.

CUNHA, T. M.; CASTRO, F. P.; BARRETO, P. L. M.; BENEDET, H. D.; PRUDÊNCIO, E. S. Avaliação físicoquímica, microbiológica e reológica de bebida láctea e leite fermentado adicionados de probióticos. Semina: Ciências Agrárias, Londrina, v. 29, n. 1, p. 103-116, 2008.

FELLOEWS, P. J. Food processing technology: principles and practice. $2^{\text {th }}$ ed. Oxford: Wood Head Publishing Limited, 2000. 563 p.

FERREIRA, D. F. SISVAR: um programa para análises e ensino de estatística. Revista Symposium, Lavras, v. 6, p. $36-41,2008$.

FORSYTHE, S. J. Microbiologia da segurança alimentar. Porto Alegre, Artmed, 2002. 
GALLINA, D. A.; ALVES, A. T. S.; TRENTO, F. K. H.; CARUSI, J. Caracterização de leites fermentados com e sem adição de probioticos e prebioticos e avaliação da viabilidade de bactérias lácticas e probióticas durante a vida-de-prateleira. Revista Unopar, São Paulo, v. 3, n. 4, p. 239-244, 2011.

HAULY, M. C. O.; FUCHS, R. H. B.; PRUDÊNCIO FERREIRA, S. H. Suplementação de iogurte de soja com frutooligossacarídeos: características probióticas e aceitabilidade. Revista de Nutrição, Londrina, v. 18, n. 5 , p. 613-622, 2005.

HUNTERLAB. User's manual with universal software versions 3.5. Reston: Hunterlab, 1998.

INSTITUTO ADOLFO LUTZ - IAL. Normas analíticas do Instituto Adolfo Lutz: métodos químicos e físicos para análise de alimentos. 4. ed. São Paulo: IMESP, 2008.

LONGO, G.; MARTIM, N. S. P. P.; FREITAS, R. J. S.; FONTOURA, P. S. G. Avaliação da qualidade físicoquímica de iogurtes naturais comercializados na cidade de Curitiba, Paraná. Revista Higiene Alimentar, São Paulo, v. 20, n. 138, p. 56-59, 2006.

MACEDO, R. E. F. Desenvolvimento de bebida láctea fermentada a base de extrato hidrossolúvel de soja e soro de leite de búfala por cultura mista de lactobacillus casei Shirota e Bifidobacterium adolescentis. 1997. Dissertação (Mestrado em Tecnologia Química) Universidade Federal do Paraná, Curitiba.

MATHIAS, T. R. S.; ANDRADE, K. C. S.; ROSA, C. L. S.; SILVA, B. A. Avaliação do comportamento reológico de diferentes iogurtes comerciais. Brazilian Journal of Food Technology, Campinas, v. 16, n. 1, p. 1220, 2013.

MEDEIROS, A. C. L.; MEDEIROS, K. C. B.; MEDEIROS, M. F.; CORREIA, R. T. P. Avaliação comparativa do efeito do tratamento térmico e temperatura de incubação sobre o perfil de acidificação dos leites bovino, bubalino e caprino. Revista Brasileira de Produtos Agroindustriais, Campina Grande, v. 12, n. 2, p. 105-114, 2010.

PEREZ, K. J.; GUARIENTI, C.; COSTA, J. A. V.; COLLA, L. M. Viabilidade de bactérias láticas em iogurte adicionado de biomassa da microalga Spirulina platensis durante o armazenamento refrigerado. Alimentos $e$ Nutrição, Araraquara, v. 18, n. 1, p. 77-82, 2007.

PIMENTEL, T. C.; GARCIA, S.; PRUDENCIO, S. H. Iogurte probiótico tipo inulina de diferentes graus de polimerização: características físico-químicas e microbiológicas e estabilidade ao armazenamento. Revista Semina: Ciências Agrárias, Londrina, v. 33, n. 3, p. 1059-1070, 2012.
RIENER, J.; NOCI, F.; CRONIN, D. A.; MORGAN, D. J.; LYNG, J. G. A comparison of selected quality characteristics of yoghurts prepared from thermosonicated and conventionally heated milks. Food Chemistry, London, v. 119, n. 3, p. 1108-1113, 2010.

ROCHA, E. M. Análise sensorial e estudo de vida de prateleira de sobremesas lácteas à base de frutas tropicais. Revista Higiene Alimentar, São Paulo, v. 19, n. 135, p. 28-33, 2005 .

SALES, S. S.; COSTA, F. N.; ALVES, L. M. C.; SOUSA, J. G. M.; MACHADO, P. P. Avaliação da qualidade microbiológica de iogurtes de produção regional, comercializados no município de São Luís, MA. Revista Higiene Alimentar, São Paulo, v. 21, n. 157, p. 118-122, 2007.

SHAH, N. P. Probiotic bacteria: selective enumeration and survival in dairy foods. Journal of Dairy Science, Lancaster, v. 83, n. 4, p. 894-907, 2000.

SILVA, A. R.; MENDES e MORO, L.; PINTO, E. G.; SOUZA, A. F.; FRANCO, B. Estudo do comportamento cinético e reológico da fermentação lática na produção de iogurte natural. Enciclopédia Biosfera, Centro Científico Conhecer, Goiânia, v. 8, n. 14, p. 1907-1913, 2012.

SILVA, V. A. M.; RIVAS, P. M.; ZANELA, M. B.; PINTO, A. T.; RIBEIRO, M. E. R.; SILVA, F. P.; MACHADO, M. Avaliação da qualidade físico-química e microbiológica do leite cru, do leite pasteurizado tipo a e de pontos de contaminação de uma granja leiteira no RS. Acta Scientiae Veterinariae, Porto Alegre, v. 38, n. 1, p. 51-57, 2010.

SOUZA, L. G.; SANTOS, G. T.; SAKAGUTI, E. S. Avaliação da composição do leite UHT proveniente de dois laticínios das regiões Norte e Noroeste do Estado do Paraná. Acta Scientiarum. Animal Sciences, Maringá, v. 26, n. 2, p. 259-264, 2004.

SOUZA, M. C.; TEIXEIRA, L. J. Q.; ROCHA, C. T.; FERREIRA, G. A. M. F.; LIMA FILHO, T. Emprego do frio na conservação de alimentos. Revista Enciclopédia Biosfera, Centro Cientifico Conhecer, Goiânia, v. 9, n. 16, p. 1027-1046, 2013.

THAMER, G. K.; PENNA, B. L. A. Efeito do teor, açúcar e de frutooligossacarídeos sobre a população de bactérias em bebidas fermentadas. Revista Brasileira de Ciências Farmacêuticas, São Paulo, v. 41, n. 3, p. 394-400, 2005.

VÉTIER, N.; BANON, S.; CHARDOT, V.; HARDY, J. Effect of temperature and aggregation rate on the fractal dimension of renneted casein aggregates. Journal of Dairy Science, Madison, v. 86, n. 8, p. 2504-2507, 2003. 
